\title{
Building effective policies to conserve pollinators: translating knowledge into policy Barbara Gemmill-Herren ${ }^{1,2}$, Lucas A Garibaldi ${ }^{3,4}$, Claire Kremen ${ }^{5}$ and Hien $\mathrm{T} \mathrm{Ngo}^{6}$
}

Pollination management recommendations are becoming increasingly precise, context-specific and knowledge-intensive. Pollination is a service delivered across landscapes, entailing policy constructs across agricultural landscapes. Diversified farming practices effectively promote pollination services. Yet it remains difficult to secure large-scale uptake by farming communities. A strong foundation upon which to base policy formulation stems from respecting the perspective of farmers and local communities on the need to conserve pollinators, alongside scientific understanding. Ecological intensification resonates with both indigenous knowledge, local communities and scientific understanding. It emphasizes that the regulating functions of nature require both landscape-level agroecosystem design and recognition of the complexity of agricultural systems. Facilitating ecological intensification across landscapes requires collective decision-making, with institutional innovation in local structures and food system governance.

\footnotetext{
Addresses

${ }^{1}$ Prescott College, 220 Grove Ave., Prescott, AZ 86301, USA

${ }^{2}$ World Agroforestry Center, United Nations Avenue, Gigiri, Nairobi, Kenya

${ }^{3}$ Universidad Nacional de Río Negro, Instituto de Investigaciones en Recursos Naturales, Agroecología y Desarrollo Rural, San Carlos de Bariloche, Río Negro, Argentina

${ }^{4}$ Consejo Nacional de Investigaciones Científicas y Técnicas, Instituto de Investigaciones en Recursos Naturales, Agroecología y Desarrollo Rural, San Carlos de Bariloche, Río Negro, Argentina

${ }^{5}$ Institute for Resources, Environment and Sustainability and Department of Zoology, 2202 Main Mall, The University of British Columbia, Vancouver, British Columbia V6T 1Z4, Canada

${ }^{6}$ Food and Agriculture Organization of the United Nations, Office of Climate Change, Biodiversity and Environment, 00153 Rome, Italy

Corresponding author:

Gemmill-Herren, Barbara (b.gemmillherren@prescott.edu)
}

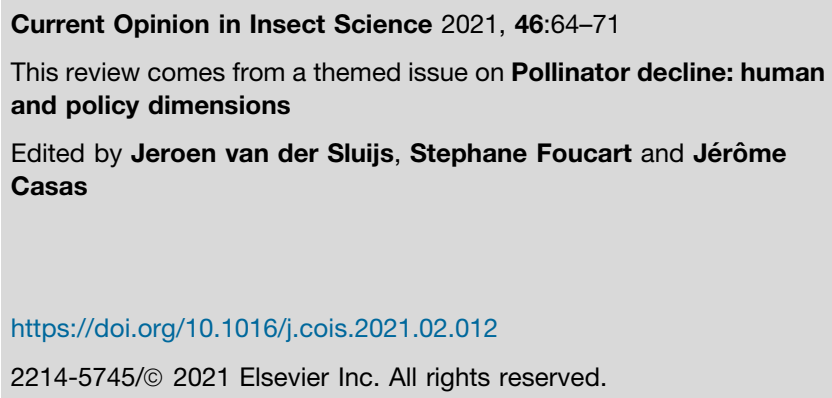

\section{Introduction}

Policy measures to address conservation of pollinators in agroecosystems have been on the global agenda since at least 2002, when the Convention on Biological Diversity established the International Pollinators Initiative and requested the Food and Agriculture Organization of the United Nations (FAO) to facilitate the initiative. The International Pollinator Initiative coordinated by FAO has provided initial guidance on policy development [1]. Two additional important initiatives have been developed over this time, also seeking to identify effective actions to conserve and protect pollinators: the Millennium Ecosystem Assessment (MEA), and the Intergovernmental Science-Policy Platform on Biodiversity and Ecosystem Services (IPBES). The Millennium Ecosystem Assessment, called for by the United Nations Secretary-General Kofi Annan in 2000, brought the term 'ecosystem services' into currency, codifying the concept that nature is capable of providing multiple benefits to people. The IPBES, an intergovernmental body, was established in 2012 to carry out assessments to catalyze a positive transformation within the elements and interlinkages that currently drive losses in biodiversity and ecosystem services. The first thematic assessment undertaken by IPBES was on pollinators, pollination and food production [2] which included a summary for policymakers [3] that was accepted and approved in 2016 by all member States of IPBES.

These various assessments have revealed that while the scientific study of pollination, and ecosystems services has advanced greatly over the last twenty years, a divide continues between science, knowledge and policy. As we explore below in 'State of knowledge to underpin policy formulation' the science of pollination services is becoming increasingly exact and focused and is articulated as a suite of management practices. Yet the engagement of the farming community to put into place such management measures to conserve and protect pollinators remains elusive around the world. We trace the existing discourse around pollinatorfocused policy ('Knowledge into Policy'), and highlight aspects that can contribute to more all-encompassing, effective policy formulation ('Crafting Policies').

\section{State of knowledge to underpin policy formulation: pollination services}

On a farm level, land managers rarely monitor the levels of crop pollination needed to guide farming decisions. 
The few existing pollination recommendations focus on a particular number of honey bee or bumble bee hives per crop area and expected yields (e.g., Ref. [4]), but these still widely used guidelines do not accurately predict the actual pollination services that crops receive $\left[5^{\bullet \bullet}\right]$. The amount of pollination services received also depends on the intrinsic features of the crop itself and the habitat context, including the attractiveness of neighbouring vegetation (which could compete with or facilitate visits to crop flowers) and the abundance and richness of wild pollinators that visit crops $\left[5^{\circ \bullet}\right]$. Thus, pollination management for pollinator-dependent crops should be based on context-specific information - that is, direct measures of pollinator activity, which can be accomplished by monitoring flower visitation rates $\left[6^{\bullet \bullet}\right]$.

Existing research suggests that higher flower-visitor richness is generally better for crop pollination (i.e., linear relation; $\left.\left[7^{\circ \bullet}\right]\right)$. Thus, managing for pollinator richness is a critical goal for the delivery of pollination services. Although there are no target values established for pollinator richness, monitoring richness and trying to maximize it is good practice. Highly abundant, single pollinator species cannot replace the beneficial effects of pollinator richness over space and time, so species richness effects are complementary to those from abundance $\left[7^{\bullet \bullet}, 8,9\right]$. The benefits attributed to richness may come from several, non-exclusive mechanisms (as reviewed in Refs. $[10,11])$, including that different pollinator species handle flowers differently, visit flowers at different times of the day [12,13], change the behaviour of other pollinator species [14,15], increase the chance that an effective pollinator is present in the community $\left[16^{\circ}, 17\right]$, or respond differentially to weather or other environmental conditions [15].

In addition to recognizing the contribution of both abundance and richness to optimal crop pollination, specifically encouraging native pollinator communities over introduced managed pollinators is a further management and policy consideration. Diverse and abundant native pollinator communities can provide effective pollinator services $\left[18^{\bullet \bullet}\right]$, and are often as or more effective than managed pollinators per-visit in providing these services $[8,19]$.

\section{State of knowledge to underpin policy formulation: management practices}

Pollination is an ecosystem service that is generated across scales, from farm or site-scale to landscape-scale. Thus, once a specific crop pollination need and deficit is determined, delivery of pollination services becomes both a management issue on farms, and a policy challenge across agricultural landscapes. In seeking to identify cohesive policy measures to facilitate the practices needed to conserve and sustain pollinators in agricultural landscapes, attention has turned to diversified farming systems. A diversified farming system incorporates crop and non-crop vegetative diversity through diversification practices at three scales: within crop fields (e.g., polyculture, crop rotation and companion plantings), around crop fields (e.g., floral strips and hedgerows) and in the larger farming landscape (e.g., fallow fields, heterogeneous row crops and orchards, pastures, woodlands and riparian forests). By promoting beneficial organisms, diversified farming systems generate and regenerate a suite of ecosystem services that promote crop production, from soil fertility and water infiltration to crop pollination and pest control, thus reducing farmer reliance on purchased inputs such as fertilizers, pesticides and managed bees [20].

Improvements to pollinator diversity occur in response to diversification practices at each of these scales; such effects can be cumulative or positively interactive across scales [21,22]. Only a few studies have examined how crop diversity itself affects pollinator communities, but those that do find enhanced native pollinator abundance in response to increased crop diversity [ $\left.23^{\circ \bullet}\right]$. At the infield scale, strong global meta-analysis evidence shows a positive response of pollinator abundance and richness to vegetative diversity overall [24]. Around field perimeters in studies in North America and Europe, there is strong experimental support both for annual flower strips $\left[22,25^{\circ \bullet}\right]$ and perennial hedgerows $\left[26^{\bullet \bullet}\right]$ for their positive effects on pollinator abundance, richness and even persistence [27]. However, these increases do not always increase pollination services or crop yields in the adjacent crop, as documented in North America, Europe and New Zealand [28 ${ }^{\circ}$, despite the strong overall relationship between pollinator abundance and richness and crop yield found in a global, quantitative synthesis [ $\left[8^{\bullet \bullet}\right]$. This mismatch is likely due to lack of fine-tuning between the floral resources added, the pollinator species they support, and the pollinators needed for the specific crop $\left[25^{\bullet}, 28^{\bullet}\right]$, strongly supporting the earlier point that managing for optimal pollination services is context-specific. In a European meta-analysis $\left[2^{\circ}\right]$ landscapes with high edge densities supported the highest levels of pollinators and natural enemies. Finally, at the landscape scale, the loss of semi-natural habitat patches in the surrounding landscape unequivocally depresses pollinator abundance and richness [30], leading to reduced pollination services and yields $\left[18^{\bullet \bullet}\right]$.

In addition to the availability of floral resources, the provisioning of resources for pollinator nesting habitats is crucial to sustaining native pollinators in agroecosystems. Perennial habitats provided by hedgerows and remnant vegetation may support bee nesting, and indirect evidence suggests that these habitats particularly support bees that nest in cavities above-ground [ $\left.31^{\circ}\right]$.

One aspect of field-level management that has serious implications for pollinators is pesticide application 
practices. While pesticides are targeted at pest organisms, there is ample evidence of ancillary harm caused to pollinating agents, not just from active agents but also from some of the inert components of pesticides [32]. Relative to their potency, modern insecticides are applied at higher rates than DDT [33], which suggests the failure of current pesticide policy. Further, Integrated Pest Management relies on careful monitoring to assess pest damage thresholds before applying pesticides in order to minimize their use. Yet as seed coatings such as neonicotinoids are now a primary delivery route for plant protection, pesticide application now precedes assessment of pest occurrence, increasing pesticide use in a manner that is not always warranted [33]. While predators of crop pests also often respond positively to the habitat management measures highlighted for pollinators $\left(\left[18^{\bullet \bullet}, 28^{\bullet}, 34,35\right]\right.$; but see Ref. [36 $\left.\left[6^{\circ}\right]\right)$, they too are heavily impacted by pesticide application practices.

Finally, the level of understanding of pesticide impacts on pollinators, such that it can translated into effective and protective policy, has been criticized as being a 'catalogue of complexities' - with somewhat disjointed evidence on exposure levels, interactions and synergies, sublethal effects, and more. Because little understanding exists of either the upstream processes driving exposure to pesticides (e.g., the increases in rates, overall toxicity and delivery routes), and downstream, system-level outcomes on agricultural and natural ecosystems are poorly understood $\left[37^{\circ}\right]$, it is difficult to create effective and protective pesticide policy for pollinators. We therefore aim instead to promote diversified farming practices. These practices can lead to simultaneous improvements in both pollination services and nautral pest control $\left[18^{\bullet \bullet}, 28^{\bullet}, 38,39\right]$, and thus to diminished use of pesticides and attendant costs for farmers $\left[38,40^{\circ}\right]$. With appropriate information, farmers are likely to reduce pesticide application rates, which are typically often over applied [41].

Thus, actions to manage, protect and conserve pollinators are reasonably well known, and well documented: to ensure that there are sufficient floral and nesting resources for pollinators across time and the space in an agricultural landscape, and to reduce or eliminate pesticide use, through natural means of pest control that are not toxic to bees.

\section{Translating knowledge into effective policy}

Despite this knowledge, it has proven difficult to secure large-scale uptake of diversified farming systems by farming communities. Trends go in the opposite direction globally; agriculture is becoming more simplified and intensified, with greater pesticide use $\left[42^{\circ}\right]$. These trends are associated with exactly the characteristics that have been shown detrimental to pollinators: increased field sizes, reduced crop diversity and semi-natural habitat, which are in turn associated with reduced plant [43] and pollinator diversity $\left[18^{\bullet \bullet}, 21,24,29^{\bullet}\right]$.

Policies mitigating the environmental impacts of agriculture and promoting improvements traditionally take many forms, primarily working through 'carrots' (positive incentives for good practice) and 'sticks' (regulatory mandates for good practice fortified by penalties for not using those practices). As trends in the negative externalities of agriculture continue to increase, it can be argued that the basic premise for such policies needs rethinking. Even within the EU, where a targeted 'Pollinators Initiative' was launched in 2018 by the European Commission, a special report of the Europe Court of Auditors in 2020 found that the EU continues to lack a consistent approach to the protection of wild pollinators, failing to adequately integrate biodiversity conservation with agricultural measures and to address relevant pesticide risks [44]. Questions remain as to why, even where agri-environmental schemes have rewarded farmers for introducing measures on-farm to support pollinator conservation, too often they have not met expectations [ $45^{\circ}$ ]. Farmers have often adhered to requirements but not to the management (and commitment needed) to create pollinator-supportive farm environments [46]. A better understanding of the state of knowledge and perspective of farmers and local communities on the need to conserve and promote pollinators, could be a stronger evidence base upon which to base policy formulation.

In this respect, the overarching framework from which the work of IPBES and its pollination assessment is based on is of great relevance. The IPBES conceptual framework has sought to represent the relationships between people and nature, and their diverse knowledge systems. This stems from an explicit recognition that different knowledge systems, including those of indigenous peoples and local communities (IPLCs), are important for a comprehensive assessment of nature, its state, trends, (indirect) drivers and what policy and governance options are available for decision makers [47,48].

Some of the key innovations within IPBES that lend themselves to strengthening the knowledge base for better policy formulation $\left[49^{\circ}\right]$ have been:

- Use of a systematic literature review method (modified from Ref. [50]) where appropriate, to reduce bias and include as much relevant and current evidence as possible to increase the credibility of the report;

- Deliberate inclusion of different knowledge systems including indigenous and local knowledge (ILK) and understanding of pollinators, and their valuation. An ILK dialogue was piloted during the development of the IPBES pollination assessment report as a method of co-producing and sharing knowledge to complement the scientific evidence base. Hill et al. [51 ${ }^{\bullet \bullet}$ ] highlighted 
three broad categories emerging from this dialogue indicating that IPLC (indigenous people and local communities) practices can be significant for pollinator conservation: 1) the practice of valuing diversity and fostering biocultural diversity; 2) landscape management practices; and 3) diversified farming systems.

The IPBES process has underscored that science-policy interfaces and their knowledge products (i.e., assessments) - to be successful and effective - have to be credible, relevant and legitimate $\left[48,52,53^{\circ}\right]$. The IPBES assessment process has effectively built the needed credibility and legitimacy through its process of engaging the scientific community and indigenous knowledge holders; its relevancy is secured through the mandate being given by Governments themselves and the Governments' role in the final approval process of an assessment's summary for policymakers.

IPBES is not alone; there is increasing recognition of the importance of including different knowledge systems into evidence-based policy-relevant documents and assessments targeted at decisionmakers $\left[54^{\bullet \bullet}, 55\right]$. With the appropriate approach, this deliberate inclusion can be quite influential. Current examples are the newly formed Local Communities and Indigenous Peoples Platform (LCIPP) of the United Nations Framework Convention on Climate Change (UNFCCC) $\left[56^{\circ}\right.$ ] and the Local Biodiversity Outlook Series [57]. The latter summarizes on-the-ground initiatives contributing to biodiversity conservation, and incorporates, for example, the local communities recognition of the value of certain trees to pollinators and the taste of honey in northern Thailand. These knowledge sources will directly inform the post2020 global biodiversity framework negotiations of the Convention on Biological Diversity (CBD). The inclusion of indigenous and local knowledge will better inform and evolve the policymaking processes for these international environmental treaties.

\section{Crafting more effective policies}

Building on the IPBES assessment report, expert opinion has identified, with variable certainty and regional variability, key pressures driving pollinator decline (Dicks, under submission). These conclusions suggest that policy responses should reduce pressures from land cover change, land management and pesticides. These priorities mirror, to a good extent, the practices identified by IPLC knowledge holders, above and form a consistent basis for creating future policy.

However, in the face of continued biodiversity loss in general $\left[58^{\bullet \bullet}\right]$ and insect declines in particular [59 ${ }^{\circ}$, questions still remain around what are the specific, targeted policy formulations - beyond general recommendations - that will effectively avoid, slow or reverse such trends?
Lists of specific policy recommendations for pollination services have been put forward [60], focusing on reducing risks from pesticides, supporting sustainable farming, enhancing biodiversity to generate ecosystem services, and increasing knowledge. Yet farmers and policymakers are equally unlikely to focus singularly on pollination services alone, out of all those that underpin sustainable production. Seeking a more overarching approach, it can be noted that all such measures more generally fall within the scope of 'ecological intensification', with an overall aim to maintain or increase agricultural productivity through promoting ecosystem services to replace synthetic agricultural inputs $\left[61,62^{\bullet \bullet}\right]$. Recent research indicates that ecological intensification, through diversification, often enhances ecosystem services such as biodiversity, pollination, pest control, nutrient cycling, soil fertility and water regulation while maintaining crop yields $\left[63^{\circ}\right]$.

Ecological intensification particularly resonates with the carefully identified pollinator policy [64]. While many approaches to sustainable agriculture tend to focus on increasing efficiencies at the level of agricultural fields, current expositions of ecological intensification, by contrast, stress that making use of the regulating functions of nature requires landscape-level agroecosystem design $[10,65]$ and recognition of the complexity of agricultural systems [ $\left[66^{\circ}\right]$. They also note that ecologically intensive practices take time and often specialized knowledge to deliver results, and should involve support for farmer training, participatory action research and the reinforcement of social capital $\left[62^{\bullet \bullet}, 67^{\bullet \bullet}\right]$. Multiple transition pathways are possible, to convert intensive agriculture, particularly on land which has begun to lose productivity due to long-term conventional intensification, back to diversified and productive agroecosytems, restoring the benefits of nature through the application of diversity and knowledge (Figure 1).

Such a wholesale shift from conventional agriculture with its strong dependencies on fossil fuels and agricultural chemicals to one that replaces the inherent structures creating such dependencies is not a simple task. It is best seen, at the minimum, as a transition in technological innovation, beyond input substitution to system redesign $\left[66^{\circ}\right]$. However, those measures to facilitate ecological intensification and management across landscapes will often require collective decision-making, thus calling for institutional innovation in local structures and food system governance (i.e., transformative change). Such innovation has deep implications: as examined in the recent Committee on World Food Security High-Level Panel of Experts report on Agroecology and other Innovations $\left[68^{\circ \bullet}\right]$, innovation for sustainable food systems requires (i) inclusive and participatory forms of innovation governance; (ii) information and knowledge co-production and sharing among communities and networks; and (iii) 


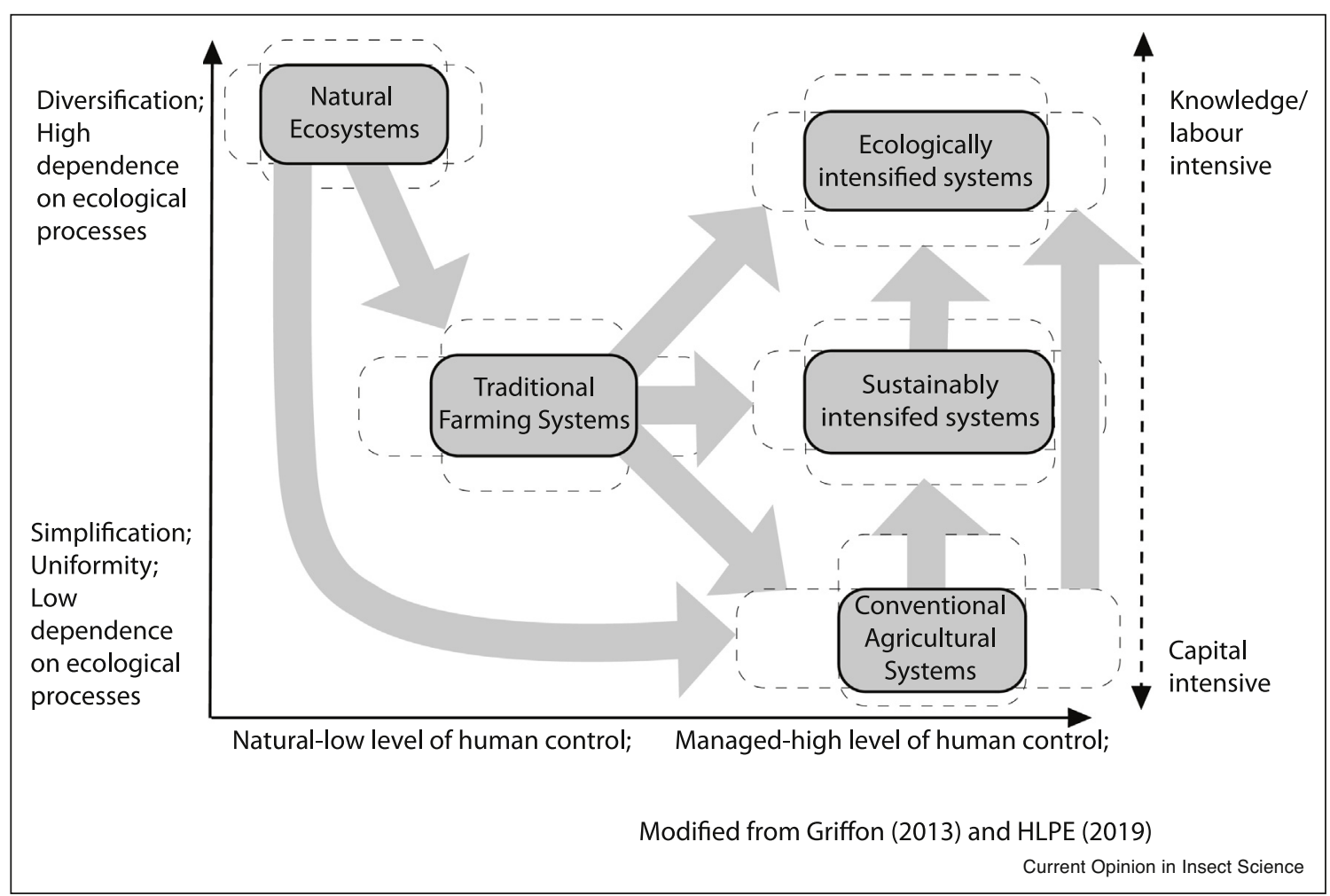

Multiple transition pathways of agricultural systems.

The dotted lines around nodes indicate variability in status of different types of system and dotted arrows indicate variable and multiple transition pathways between states. Grey arrows indicate predominant transitions [69].

responsible innovation that steers innovation towards social issues. Without these social innovations, solely technological innovations will not be readily adopted and embraced.

In summary, we have sought to highlight the essential ingredients of effective pollinator conservation policy, based on the latest scientific understanding and those from different knowledge systems, of pollination services, the requirement for cross-scalar management from farms to landscape scale, and the current pollinator policy discourse. To move beyond lists of policy recommendations, we have sought to identify systemic solutions that respond to the identified needs for co-creation of knowledge with farmers, effective, inclusive and participatory approaches to decision making and innovations in governance to management across agroecosystem landscapes. Successful policy formulation must extend beyond the concerns of pollination services and progress to be more holistic and cross-cutting with opportunities for engagement with all relevant actors at each decision-making entry point in the transition to sustainable food systems.

\section{Funding statement}

This research did not receive any specific grant from funding agencies in the public, commercial, or not-forprofit sectors.

\section{Declaration of interest}

None.

\section{References and recommended reading}

Papers of particular interest, published within the period of review, have been highlighted as

- of special interest

-• of outstanding interest

1. Rose T, Kremen C, Thrupp A, Gemmill-Herren B, Graub B, Azzu N: Policy Analysis Paper: Mainstreaming of Biodiversity and Ecosystem Services with a Focus on Pollination. Rome, Italy: Food and Agriculture Organization of the United Nations; 2015.

2. IPBES: The Assessment Report of the Intergovernmental SciencePolicy Platform on Biodiversity and Ecosystem Services on Pollinators, Pollination and Food Production. Bonn, Germany: Secretariat of the Intergovernmental Science-Policy Platform on Biodiversity and Ecosystem Services; 2016. 
3. IPBES: Summary for Policymakers of the Assessment Report of the Intergovernmental Science-Policy Platform on Biodiversity and Ecosystem Services (IPBES) on Pollinators, Pollination and Food Production. Bonn, Germany: Secretariat of the Intergovernmenta Science-Policy Platform on Biodiversity and Ecosystem Services; 2016.

4. Free JB: Insect Pollination of Crops. Academic press; 1993.

5. Rollin O, Garibaldi LA: Impacts of honeybee density on crop -• yield: a meta-analysis. J Appl Ecol 2019, 56:1152-1163. The relationship between honeybee colony density and floral visitation rates with crop productivity was analyzed. Both were found to increase crop productivity, but results suggested optimal levels, past which greater visitation may not be beneficial. Benefits of honeybee pollination moreover may vary with crop biology. The results suggest a more nuanced approach to management recommendations.

6. Garibaldi LA, Sáez A, Aizen MA, Fijen T, Bartomeus I: Crop

-. pollination management needs flower-visitor monitoring and target values. J Appl Ecol 2020, 57:664-670.

Direct measures of pollinator activity are proposed as an accurate means of monitoring levels of crop pollination, and a protocol is described to carry out such measures. Target values of visitation rates for maximum crop yields are provided, by considering the number of visits per flower needed for full fertilization. Flower monitoring programmes, using these measures, are proposed to improve the management of crop pollination.

7. Garibaldi LA, Carvalheiro LG, Vaissière BE, Gemmill-Herren B,

- Hipólito J, Freitas BM, Ngo HT, Azzu N, Sáez A, Åström J et al.: Mutually beneficial pollinator diversity and crop yield outcomes in small and large farms. Science 2016, 351:388-391.

8. Garibaldi LA, Steffan-Dewenter I, Winfree R, Aizen MA, Bommarco R, Cunningham SA, Kremen C, Carvalheiro LG, Harder LD, Afik $\mathrm{O}$ et al.: Wild pollinators enhance fruit set of crops regardless of honey bee abundance. Science 2013, 339:1608-1611.

9. Fijen TP, Scheper JA, Boom TM, Janssen N, Raemakers I, Kleijn D: Insect pollination is at least as important for marketable crop yield as plant quality in a seed crop. Ecol Lett 2018, 21:17041713.

10. Tscharntke T, Klein AM, Kruess A, Steffan-Dewenter I, Thies C: Landscape perspectives on agricultural intensification and biodiversity-ecosystem service management. Ecol Lett 2005, 8:857-874

11. Klein AM, Müller $\mathrm{C}$, Hoehn $P$, Kremen C: Understanding the Role of Species Richness for Crop Pollination Services. Biodiversity, Ecosystem Function and Human Wellbeing. New York: Oxford University Press; 2009, 195-208.

12. Hoehn P, Tscharntke T, Tylianakis JM, Steffan-Dewenter I: Functional group diversity of bee pollinators increases crop yield. Proc R Soc B Biol Sci 2008, 275:2283-2291.

13. Fründ J, Dormann CF, Holzschuh A, Tscharntke T: Bee diversity effects on pollination depend on functional complementarity and niche shifts. Ecology 2013, 94:2042-2054.

14. Carvalheiro LG, Veldtman R, Shenkute AG, Tesfay GB, Pirk CW, Donaldson JS, Nicolson SW: Natural and within-farmland biodiversity enhances crop productivity. Ecol Lett 2011, $14: 251-259$.

15. Brittain C, Williams N, Kremen C, Klein AM: Synergistic effects of non-Apis bees and honey bees for pollination services. Proc $R$ Soc B Biol Sci 2013, 280:20122767.

16. Winfree R, Reilly JR, Bartomeus I, Cariveau DP, Williams NM,

- Gibbs J: Species turnover promotes the importance of bee diversity for crop pollination at regional scales. Science 2018 359:791-793.

The authors show that due to rates of species turnover, the number of bee species needed is much larger in natural environments than that reflected in limited field experiments. It is suggested that maintaining ecosystem services in nature requires high levels of species diversity, including relatively rare species.

17. Schleuning M, Fründ J, García D: Predicting ecosystem functions from biodiversity and mutualistic networks: an extension of trait-based concepts to plant-animal interactions. Ecography 2015, 38:380-392.
18. Dainese M, Martin EA, Aizen MA, Albrecht M, Bartomeus I,

-• Bommarco R, Carvalheiro LG, Chaplin-Kramer R, Gagic V. Garibaldi LA et al.: A global synthesis reveals biodiversitymediated benefits for crop production. Sci Adv 2019, 5: eaax0121.

The relative importance of species richness, abundance, and dominance in the delivery of the ecosystem services of pollination, biological pest control, and crop production was assessed. Richness was the characteristic that most directly support these ecosystem services, and simplification had negative consequences for crop yields.

19. Rader R, Bartomeus I, Garibaldi LA, Garratt MP, Howlett BG, Winfree R, Cunningham SA, Mayfield MM, Arthur AD, Andersson GK et al.: Non-bee insects are important contributors to global crop pollination. Proc Natl Acad SciU S A 2016, 113:146-151.

20. Kremen C, lles A, Bacon C: Diversified farming systems: an agroecological, systems-based alternative to modern industrial agriculture. Ecol Soc 2012, 17.

21. Kennedy CM, Lonsdorf E, Neel MC, Williams NM, Ricketts TH, Winfree R, Bommarco R, Brittain C, Burley AL, Cariveau D et al.: A global quantitative synthesis of local and landscape effects on wild bee pollinators in agroecosystems. Ecol Lett 2013, 16:584599.

22. Scheper J, Bommarco R, Holzschuh A, Potts SG, Riedinger V, Roberts SP, Rundlöf M, Smith HG, Steffan-Dewenter I, Wickens JB et al.: Local and landscape-level floral resources explain effects of wildflower strips on wild bees across four European countries. J Appl Ecol 2015, 52:1165-1175.

23. Guzman A, Chase M, Kremen C: On-farm diversification in an

-• agriculturally-dominated landscape positively influences specialist pollinators. Front Sustain Food Syst 2019, 3:87.

The authors examined how field-scale diversification affects specialized pollinators in intensively managed agricultural landscapes. Diversification increased the abundance of specialized 'squash bees' but did not increase the diversity of bees visiting squash crops. However, the diversity of floral resources in polyculture farms were seen to provide a stable refuge for specialist bees over monoculture farms.

24. Lichtenberg EM, Kennedy CM, Kremen C, Batary P, Berendse F, Bommarco R, Bosque-Pérez NA, Carvalheiro LG, Snyder WE, Williams NM et al.: A global synthesis of the effects of diversified farming systems on arthropod diversity within fields and across agricultural landscapes. Glob Change Biol 2017, 23:4946-4957.

25. Nicholson CC, Ward KL, Williams NM, Isaacs R, Mason KS,

-• Wilson JK, Brokaw J, Gut LJ, Rothwell NL, Wood TJ et al.: Mismatched outcomes for biodiversity and ecosystem services: testing the responses of crop pollinators and wild bee biodiversity to habitat enhancement. Ecol Lett 2020, 23:326-335

The authors tested whether management of habitat adjacent to crops increases pollinator abundance and diversity. These were increased where field edges were enhanced, but the abundance and diversity of bees visiting crops was not increased. The conditions under which biodiversity and ecosystem services may best be co-managed need further investigation.

26. Kremen C, Albrecht M, Ponisio LC: Restoring pollinator -. communities and pollination services in hedgerows in intensively-managed agricultural landscapes. The Ecology of Hedgerows and Field Margins. Routledge; 2019:163-185.

This chapter in a volume on hedgerows and field margins notes the growth in pollinator-dependent crops over the last fifty years, often in the context of agricultural intensification. Agricultural intensification is well documented to impact pollinators. The understanding of how hedgerows may be managed to support populations of pollinators and the services they provide is presented.

27. M'Gonigle LK, Ponisio LC, Cutler K, Kremen C: Habitat restoration promotes pollinator persistence and colonization in intensively managed agriculture. Ecol Appl 2015, 25:15571565.

28. Albrecht M, Kleijn D, Williams NM, Tschumi M, Blaauw BR,

- Bommarco R, Campbell AJ, Dainese M, Drummond FA, Entling $\mathrm{MH}$ et al.: The effectiveness of flower strips and hedgerows on pest control, pollination services and crop yield: a quantitative synthesis. Ecol Lett 2020, 23:1488-1498. 
29. Martin EA, Dainese M, Clough Y, Báldi A, Bommarco R, Gagic V,

- Garratt MP, Holzschuh A, Kleijn D, Kovács-Hostyánszki A, Marini L: The interplay of landscape composition and configuration: new pathways to manage functional biodiversity and agroecosystem services across Europe. Ecol Lett 2019, 22:1083-1094.

30. Garibaldi LA, Steffan-Dewenter I, Kremen C, Morales JM Bommarco R, Cunningham SA, Carvalheiro LG, Chacoff NP, Dudenhöffer JH, Greenleaf SS et al.: Stability of pollination services decreases with isolation from natural areas despite honey bee visits. Ecol Lett 2011, 14:1062-1072.

31. Kremen C, M'Gonigle LK: Small-scale restoration in intensive

- $\quad$ agricultural landscapes supports more specialized and less mobile pollinator species. J Appl Ecol 2015, 52:602-610.

32. Mullin CA: Effects of "inactive" ingredients on bees. Curr Opin Insect Sci 2015, 10:194-200.

33. Cresswell JE: The impacts of agrochemical pesticides on bees in intensively cultivated farmland. In Pollination Services to Agriculture: Sustaining and Enhancing a Key Ecosystem Service. Edited by Gemmill-Herren B. 2016:155-179.

34. Letourneau DK, Armbrecht I, Rivera BS, Lerma JM, Carmona EJ, Daza MC, Escobar S, Galindo V, Gutiérrez C, López SD, Mejía JL: Does plant diversity benefit agroecosystems? A synthetic review. Ecol Appl 2011, 21:9-21.

35. Rusch A, Chaplin-Kramer R, Gardiner MM, Hawro V, Holland J, Landis D, Thies C, Tscharntke T, Weisser WW, Winqvist C et al.: Agricultural landscape simplification reduces natural pest control: a quantitative synthesis. Agric Ecosyst Environ 2016, 221:198-204.

36. Karp DS, Chaplin-Kramer R, Meehan TD, Martin EA, DeClerck F,

- Grab H, Gratton C, Hunt L, Larsen AE, Martínez-Salinas A et al.: Crop pests and predators exhibit inconsistent responses to surrounding landscape composition. Proc Natl Acad Sci U S A 2018, 115:E7863-70.

37. Sponsler DB, Grozinger CM, Hitaj C, Rundlöf M, Botías C, Code A,

- $\quad$ Lonsdorf EV, Melathopoulos AP, Smith DJ, Suryanarayanan S, Thogmartin WE: Pesticides and pollinators: a socioecological synthesis. Sci Total Environ 2019, 662:1012-1027.

38. Gurr GM, Lu Z, Zheng X, Xu H, Zhu P, Chen G, Yao X, Cheng J, Zhu Z, Catindig JL, Villareal S: Multi-country evidence that crop diversification promotes ecological intensification of agriculture. Nat Plants 2016, 2:1-4.

39. Pywell RF, Heard MS, Woodcock BA, Hinsley S, Ridding L, Nowakowski M, Bullock JM: Wildlife-friendly farming increases crop yield: evidence for ecological intensification. Proc $R$ Soc B Biol Sci 2015, 282:20151740.

40. Rosa-Schleich J, Loos J, Mußhoff O, Tscharntke T: Ecological-

- economic trade-offs of diversified farming systems-a review. Ecol Econ 2019, 160:251-263.

41. Lechenet M, Dessaint F, Py G, Makowski D, Munier-Jolain N: Reducing pesticide use while preserving crop productivity and profitability on arable farms. Nat Plants 2017, 3:1-6.

42. Ramankutty N, Mehrabi Z, Waha K, Jarvis L, Kremen C, Herrero M,

- Rieseberg LH: Trends in global agricultural land use: implications for environmental health and food security. Annu Rev Plant Biol 2018, 69:789-815.

The authors review the causes and failures of the global food system, in the context of ongoing debates over the needed pathways to achieve environmental health and food security. They call for greater coordination between plant science and agroecological approaches.

43. Fahrig L, Girard J, Duro D, Pasher J Smith A, Javorek S, King D, Lindsay KF, Mitchell S, Tischendorf L: Farmlands with smaller crop fields have higher within-field biodiversity. Agric Ecosyst Environ 2015, 200:219-234.

44. EU: Protection of Wild Pollinators in the EU - Commission Initiatives have not Borne Fruit. Luxembourg: European Court of Auditors; 2020

45. Cole LJ, Kleijn D, Dicks LV, Stout JC, Potts SG, Albrecht M,

- Balzan MV, Bartomeus I, Bebeli PJ, Bevk D et al: : A critical analysis of the potential for EU Common Agricultural Policy measures to support wild pollinators on farmland. J App/ Ecol 2020, 57:681-694

The authors evaluated how different options under the European Common Agricultural Policy vary in their potential to conserve pollinators, and how they vary in farmer uptake. Substantial variation was found in the effectiveness of options and in their management. The lack of a holistic view of implementation is flagged.

46. Dicks L, Benton T: The 'greening'of Europe's farms has been a failure. Conservation 2014, 17:2019 Online verfügbar unter https:// theconversation.com/ the-greening-of-europesfarms-has-been-a-failure-27762, zuletzt geprüft am.

47. Tengö M, Brondizio ES, Elmqvist T, Malmer P, Spierenburg M: Connecting diverse knowledge systems for enhanced ecosystem governance: the multiple evidence base approach Ambio 2014, 43:579-591.

48. Tengö M, Hill R, Malmer P, Raymond CM, Spierenburg M, Danielsen F, Elmqvist T, Folke C: Weaving knowledge systems in IPBES, CBD and beyond-lessons learned for sustainability. Curr Opin Environ Sustain 2017, 26:17-25.

49. Stevance AS, Bridgewater P, Louafi S, King N, Beard TD Jr, Van

- J Jaarsveld AS, Ofir Z, Kohsaka R, Jenderedijan K, Rosales Benites M et al: The 2019 review of IPBES and future priorities: reaching beyond assessment to enhance policy impact. Ecosyst People 2020:70-77.

This article summarizes an independent examination of IPBES' first work programme. It found, in relevance for this article, that the policy aspects of IPBES' work need to be strengthened; and a more strategic and collaborative approach to stakeholders and target audiences is needed. With strategic changes, IPBES has the potential to be a key organization catalyzing transformative change in the relationship between people and the rest of nature.

50. Collaboration for Environmental Evidence: Guidelines for Systematic Review and Evidence Synthesis in Environmental Management. Version 4.2. Environmental Evidence. Bangor University, UK: Centre for Evidence-based Conservation; 2013.

51. Hill R, Nates-Parra G, Quezada-Euán JJ, Buchori D, LeBuhn G,

-• Maués MM, Pert PL, Kwapong PK, Saeed S, Breslow SJ, da Cunha MC et al.: Biocultural approaches to pollinator conservation. Nat Sustain 2019, 2:214-222.

The authors utilized the Conceptual Framework of the Intergovernmental Platform on Biodiversity and Ecosystem Services to analyse the biocultural approaches to pollinator conservation by indigenous peoples and local communities globally. They found biocultural approaches to pollinators in conservation practices occurring in sixty countries. These approaches could be grouped into three main categories: valuation of pollinators, landscape management, and promotion of diversified farming systems.

52. Sarkki S, Niemelä J, Tinch R, Van Den Hove S, Watt A, Young J: Balancing credibility, relevance and legitimacy: a critical assessment of trade-offs in science-policy interfaces. Sci Public Policy 2014, 41:194-206.

53. Malmer P, Tengö M, Fernandez-Llamazares Onrubia A,

- Woodward ER, Crawhall N, Hill R, Trakansuphakon P, Athayde S, Carino C, Crimella D, Ferrari F: Dialogue across indigenous, local and scientific knowledge systems reflecting on the IPBES assessment on pollinators, pollination and food production. 21th to 25th January 2019, Chiang Mai and Chiang Rai, Thailand. Workshop Report. Stockholm, Sweden: SwedBio at Stockholm Resilience Centre; 2019.

54. Hill R, Adem C, Alangui WV, Molnár Z, Aumeeruddy-Thomas Y,

- Bridgewater P, Tengö M, Thaman R, Yao CY, Berkes F, Carino J. Working with indigenous, local and scientific knowledge in assessments of nature and nature's linkages with people. Curr Opin Environ Sustain 2020, 43:8-20.

55. McElwee P, Turnout E, Chiroleu-Assouline M, Clapp J, Isenhour C Jackson T, Kelemen E, Miller DC, Rusch G, Spangenberg JH, Waldron A: Ensuring a post-COVID economic agenda tackles global biodiversity loss. One Earth 2020. Sep 30.

56. Shawoo Z, Thornton TF: The UN local communities and

- Indigenous peoples' platform: a traditional ecological knowledge-based evaluation. Wiley Interdiscip Rev Clim Change 2019, 10:e575 
57. Forest Peoples Programme, International Indigenous Forum on Biodiversity, Indigenous Women's Biodiversity Network, Centres of Distinction on Indigenous and Local Knowledge, Secretariat of the Convention on Biological Diversity: Local biodiversity outlooks 2: the contributions of indigenous peoples and local communities to the implementation of the Strategic Plan for Biodiversity 2011-2020 and to renewing nature and cultures. $A$ Complement to the Fifth Edition of Global Biodiversity Outlook. Moreton-in-Marsh, England: Forest Peoples Programme; 2020

58. IPBES: Global Assessment Report on Biodiversity and Ecosystem

- Services. Bonn, Germany: Secretariat of the Intergovernmental Science-Policy Platform on Biodiversity and Ecosystem Services; 2019.

This first global assessment report from IPBES found that nature and its ecosystem functions and services deteriorating worldwide. Since 1970 the assessment finds that while trends in agriculture production have increased, pollination along with other ecosystem services are showing declining trends.

59. Wagner DL: Insect declines in the Anthropocene. Annu Rev - Entomol 2020, 65:457-480.

Declines in insect fauna are being reported from around the world. Although most reports are from western and northern Europe, additional evidence has been reported from Asia, North America, the Neotropics and other regions. Population declines, as documented in this article, are among the most concerning; abundant species anchor many trophic interactions and are responsible for many ecosystem services. Factors leading to these declines are reviewed, including some that have received less attention such as burning of fossil fuels and changing climatic patterns.

60. Dicks LV, Viana B, Bommarco R, Brosi B, del Coro Arizmendi M, Cunningham SA, Galetto L, Hill R, Lopes AV, Pires C, Taki H: Ten policies for pollinators. Science 2016, 354:975-976.

61. Bommarco R, Kleijn D, Potts SG: Ecological intensification: harnessing ecosystem services for food security. Trends Ecol Evol 2013, 28:230-238.

62. Kremen C: Ecological intensification and diversification

-. approaches to maintain biodiversity, ecosystem services and food production in a changing world. Emerg Topics Life Sci 2020, 4:229-240

This author describes how, by adding diverse vegetation into farming landscapes, the agricultural matrix can be made more habitable and permeable to biodiversity, while reducing the need for agrochemicals. It is shown that while it is possible to use single practices to 'ecologically intensify' - such as prairie strips among maize fields - comprehensive redesign of farms using multiple approaches can create holistic regenerative systems. However, barriers need to be addressed.

63. Tamburini G, Bommarco R, Wanger TC, Kremen C, van der

-• Heijden MG, Liebman M, Hallin S: Agricultural diversification promotes multiple ecosystem services without compromising yield. Sci Adv 2020, 6:eaba1715.

The impact of diversification practices on biodiversity and ecosystem services is assessed in a systematic meta-analysis, comprising more than 40000 comparisons between diversified and simplified systems. Diversification was found to enhance biodiversity, pollination, pest control, nutrient cycling, soil fertility, and water regulation without compromising crop yields, but these studies comprise considerable contextdependency.

64. Kovács-Hostyánszki A Espíndola A Vanbergen AJ, Settele J, Kremen C, Dicks LV: Ecological intensification to mitigate impacts of conventional intensive land use on pollinators and pollination. Ecol Lett 2017, 20:673-689.

65. Bianchi FJ, Booij CJ, Tscharntke T: Sustainable pest regulation in agricultural landscapes: a review on landscape composition, biodiversity and natural pest control. Proc $R$ Soc B Biol Sci 2006, 273:1715-1727.

66. Tittonell P: Ecological intensification of agriculture-

-. sustainable by nature. Curr Opin Environ Sustain 2014, 8:53-61

67. Garibaldi LA, Pérez-Méndez N, Garratt MP, Gemmill-Herren B

- Miguez FE, Dicks LV: Policies for ecological intensification of crop production. Trends Ecol Evol 2019, 34:282-286.

Policy to promote ecological intensification is not as yet well developed. Policy targets that governments can pursue for ecological intensification are proposed.

68. High Level Panel of Experts: Agroecological and other

-. innovative approaches for sustainable agriculture and food systems that enhance food security and nutrition. A Report by the High Level Panel of Experts on Food Security and Nutrition of the Committee on World Food Security, Rome. No. 14 CFS Committee on World Food Security; 2019.

Forms of innovation, in the context of sustainable food system transformations are considered in this report. The report notes that innovations in agriculture and food systems are distinct from those in many other sectors, because ecological processes and social interactions have a central role. The social innovations and governance structures needed for managing ecosystem services across landscapes are highlighted.

69. Griffon M: Qu'est ce que l'agriculture écologiquement Intensive? Editions Quae; 2013. 